MASSIVE HOUSING IN CENTRAL

NEIGHBORHOODS: WHO IS RESPONSIBLE

FOR THE EXCESSIVE DENSIFICATION?

Keywords

Vertical ghettos

Real estate

Santiago

High-rise housing

Twitter

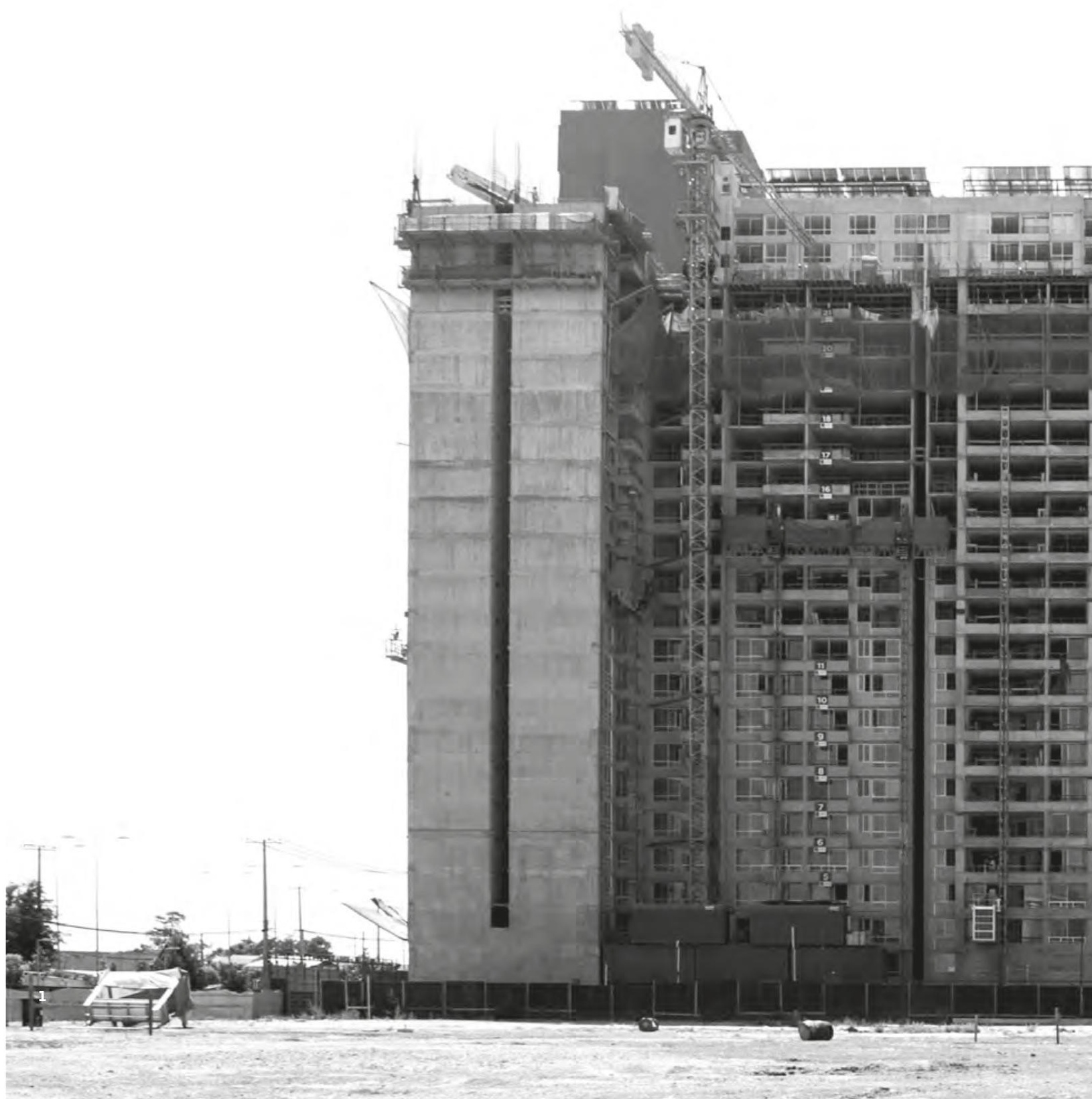




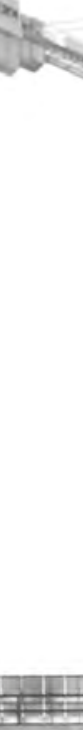

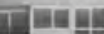

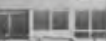
$2=$

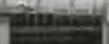
뜬 更

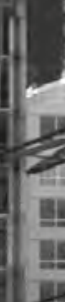
내닌.

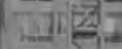
wiv $\pm$

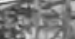
次 धी हैe? तitio 파낙가. Ex Ex: $\operatorname{lig}_{20}$

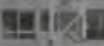

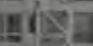

sis
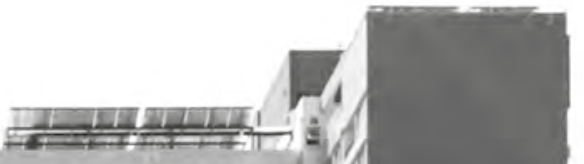

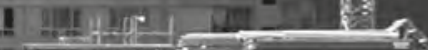

ㅁ. 경
Although the phenomenon was evident at least several years ago in various communes of Santiago, it was not until 2017 that housing hyper-densification by real estate companies exploded: a tweet by Claudio Orrego, then the mayor of the Metropolitan Santiago, put this topic on the agenda when showing the image of a real estate building of an impressive density for the local reality. After that, the controversy regarding responsibility was immediate: the State criticized the greed of the private and the permissiveness of the local government, while real estate companies defended themselves by blaming the rules. Now that the polemic has settled down, and considering that while the controversy is over the buildings are still there, we think it is necessary to return to this discussion, apropos the subject of this issue of $A R Q$ : how to make massive housing today when the State lacks the capabilities it had 50 years ago? Who is held responsible to lead in this issue? Can this problem be left only in the hands of private companies, as it has happened up to now?
1 Alto Las Rejas Las Rejas, Santiago. (c) Cristian Valenzuela 
2 Conquista Velásquez II,

Estación Central, Santiago.

(c) Cristian Valenzuela

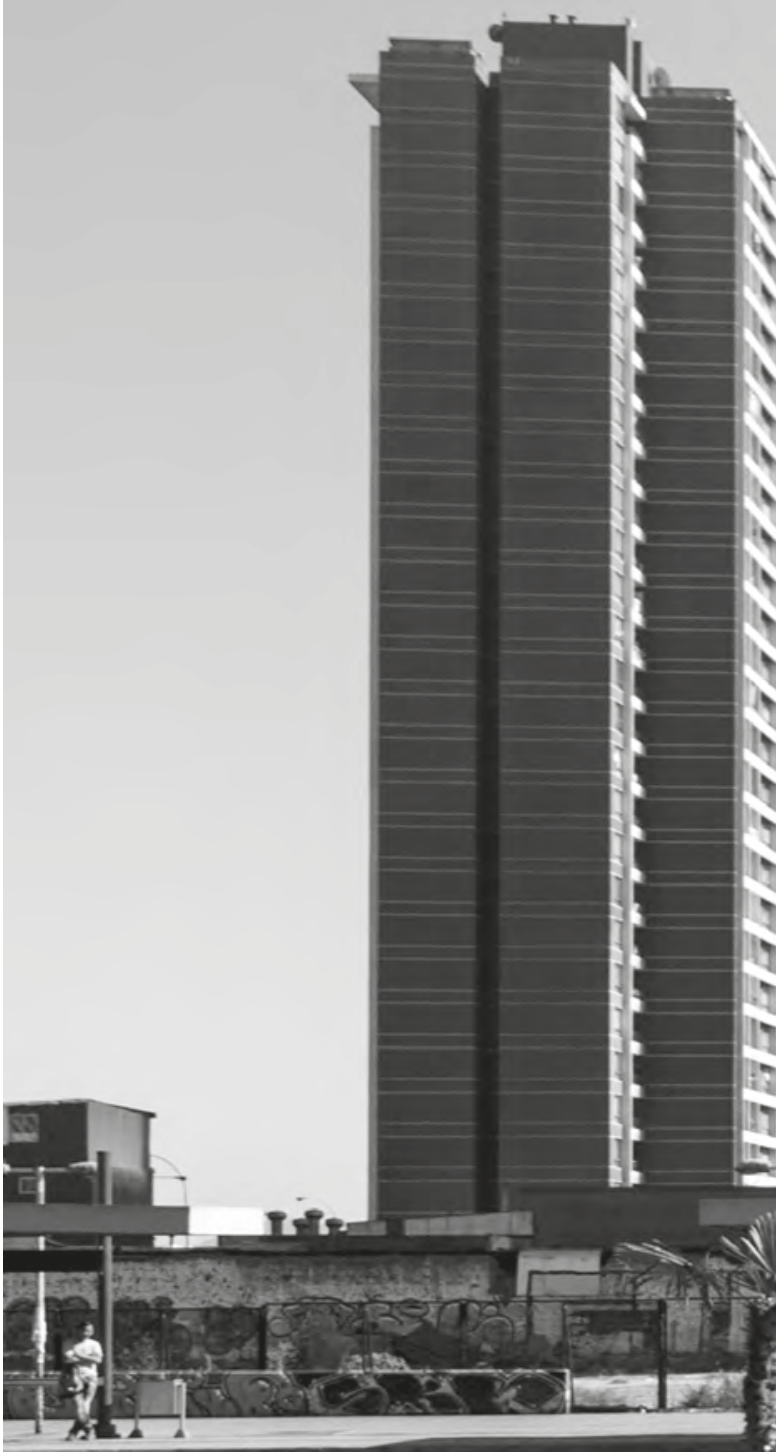

4. तो

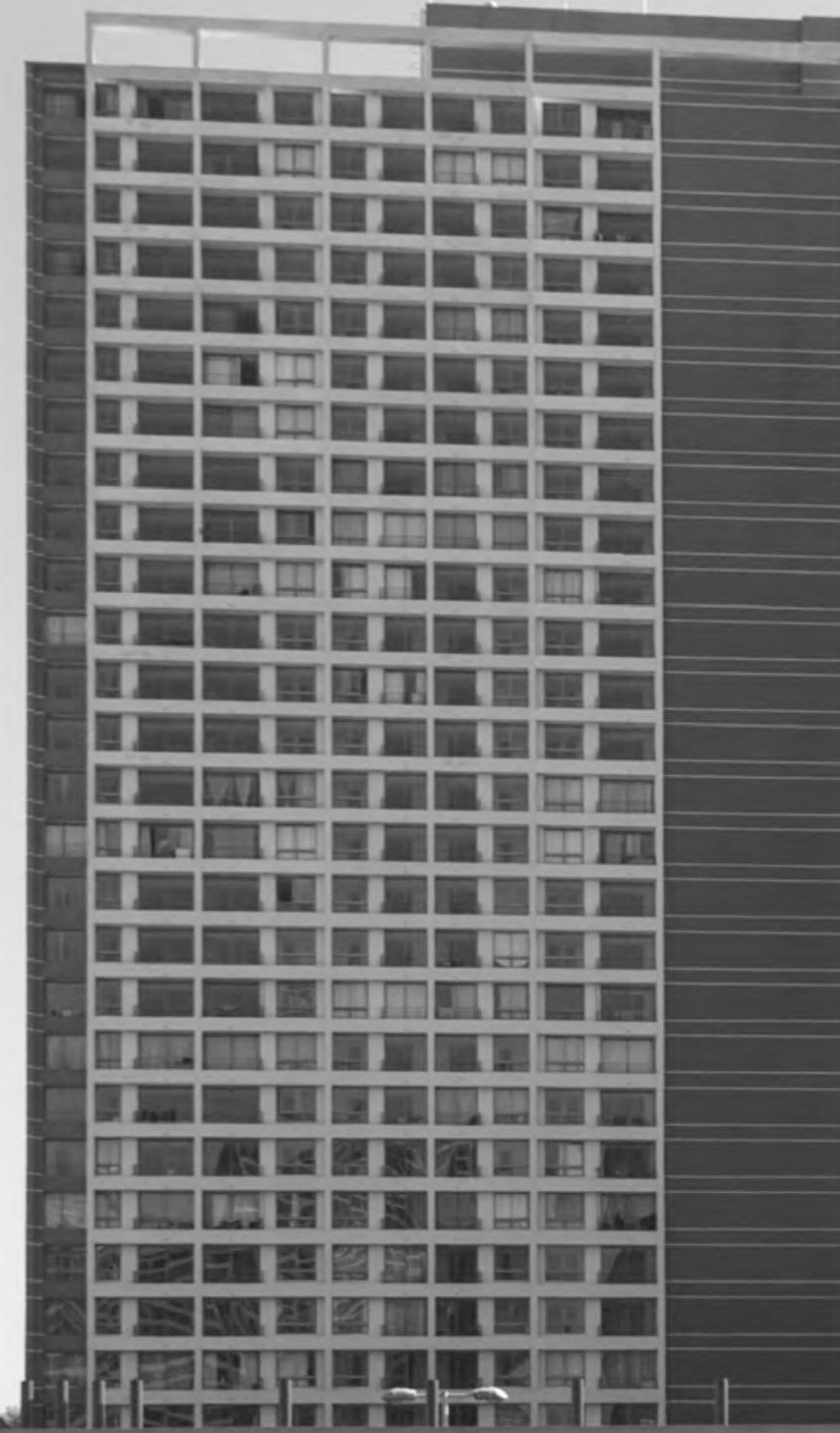
:

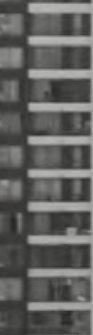

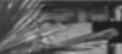

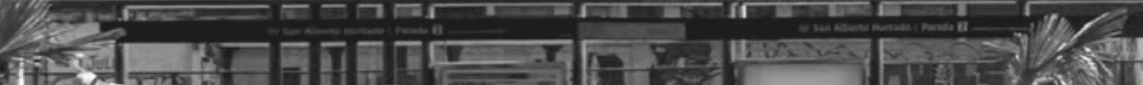




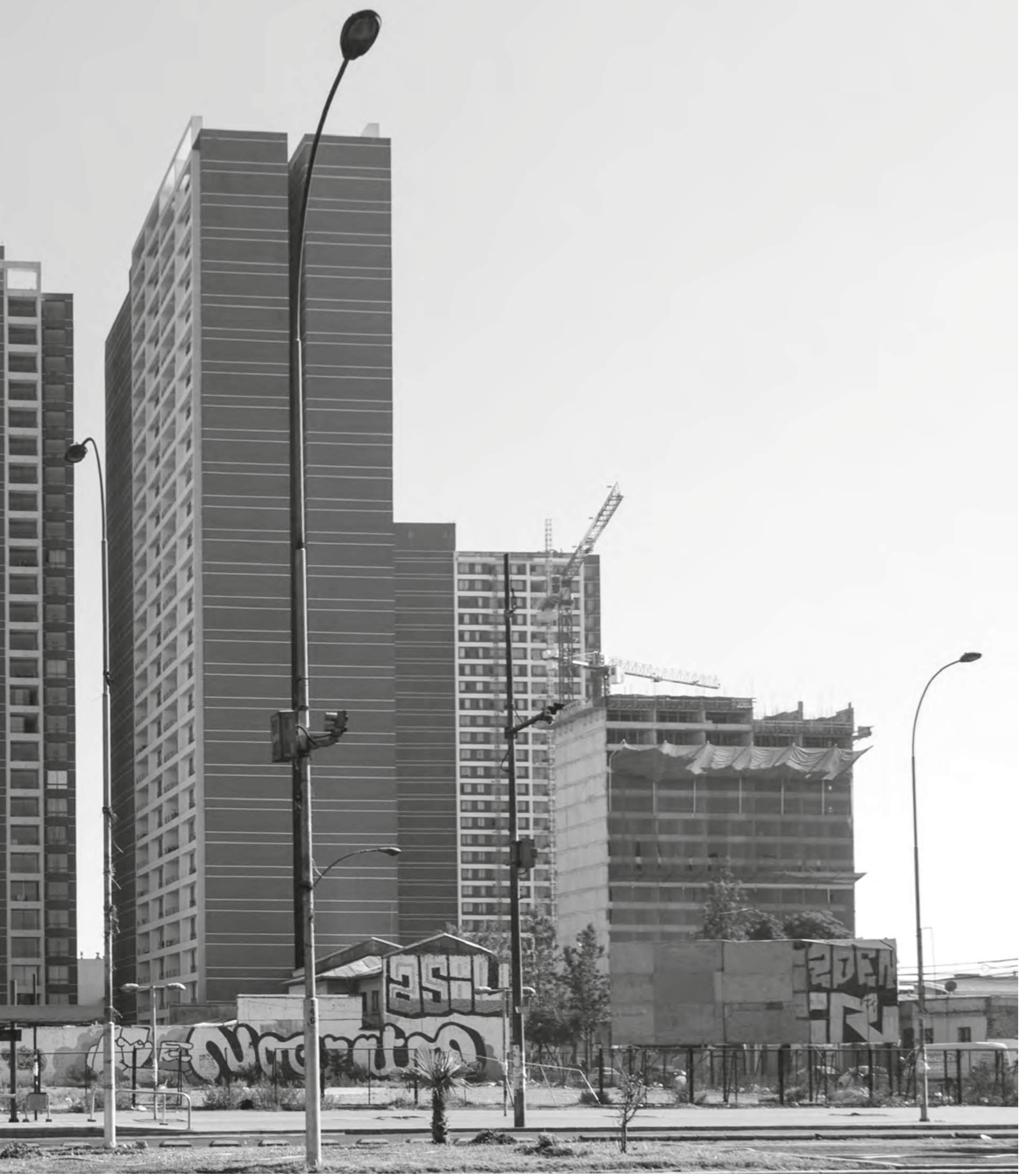



to understand the features of a society that emerged as a result of the irruption of mass consumption (this was long before Carlos Peña turned the issue into a key to reading our modernization process); today I channel most of my concerns analyzing the ins and outs of the city's vertical growth, the great urban phenomenon of the last fifteen years. As a result of this line of research, together with two other authors, we published in 2015 the book Infilling: Como cambió Santiago y nuestra forma de vivir la ciudad, two years before the hyper densification in Estación Central district became a matter of public opinion.

Strangely, such controversy did not start with the neighbors' protests - as it often happens in urban conflicts of the kind. It was the mayor of Santiago who - thanks to the publishing of a photo on Twitter gave public visibility and the proper hierarchy to an issue that had been manifesting for years. As in almost any crisis, its emergence happens when several of the agents within a system coincidentally fail. Part of the private sector was wrong. There's no doubt about that. In the real estate industry, there are agents who still do not understand the logic of legitimacy - before mere legality - at the moment of facilitating real estate investments. Hyper densification surfaced, abusing regulations and the neighborhood itself, selfishly neglecting the many negative externalities that these kinds of projects generate. The regulation, for its part, was obsolete. It always remains one step behind from what the city requires and, in this case, it is far from settling the legitimate tensions that arise between the project, the environment and the communities. Finally, the public sector - in particular Estación Central authorities in charge of initiating the elaboration of the Communal Regulatory Plan - were guilty of omission, allowing the development of projects based on PRMS's regulations, which are often insufficient, all-embracing and not detailed enough for the district's reality.

During the process of research, development, and distribution of the book - which included visiting more than ten universities throughout Chile - I was struck by the fact that schools of architecture weren't producing further academic research - articles, seminars, books thematizing and assessing the densification process taking place in our country. As it happens, the topic 


\section{ERNESTO LÓPEZ}

Profesor Asociado, Universidad de Chile, Santiago, Chile

\section{The fallacy of poverty at 'vertical ghettos'}

n April 2017, Claudio Orrego, mayor of the

Metropolitan Region, shocked public opinion with his tweet "vertical guetthos (sic) are what we are seeing in deregulated districts such as Estación Central," in reference to some of the hyper-dense high-rise housing complexes within the area.

Although the communicational success of such a phrase is indisputable, the use of the name 'ghetto' is incorrect, since it assumes high social homogeneity and internal cohesion, features absent in these complexes made out of hundreds of small units with scarce common areas and meeting spaces. The name is also cruel, as it stigmatizes the people who live in these buildings. Speaking of 'ghetto' is also ideologically deceitful, since by appealing to a class connotation it suggests that, despite all the architectural and urban horrors produced in many districts, the Chilean private real estate market builds housing for low-income population and that, in this way, it solves the need of central location for middle and low-class homes requiring it. Some even refer to it as 'high-rise social housing.'

The reality, however, is quite different. High-rise buildings erected in much of Santiago's central area are dwellings affordable mainly by middle and upper-middle segments - especially investors who buy a large number of units - and also owner-residents with savings and debt capacity who choose to live in these places. Households with lower socioeconomic status can only access this type of dwelling through multi-occupancy and in very precarious conditions.

In an unpublished study (Fondecyt \#1151287) we found that in the apartments from the real-estate boom areas at Estación Central, Independencia, Santiago Centro and San Miguel, there are no residents - either owners or tenants - belonging to socioeconomic segments $D$ and $E$, while the incidence of segments $A B C l$ and especially $C 2$ is very high, close to $60 \%$.

At Estación Central, for instance, a new apartment is no cheaper than USD 81,000 (about USD $2,700 / \mathrm{m}^{2}$ ), prices that until recently were only seen in Ñuñoa and that today characterize the high-rise housing offer in historically popular districts. In Santiago's metropolitan area, in turn, prices have not stopped climbing; in 2008 the average price for a new apartment was USD $1,800 / \mathrm{m}^{2}$, while in November 2017 it was up to USD $3,060 / \mathrm{m}^{2}$. For a market that calls itself competitive and whose production costs have not increased, prices inexplicably continue to rise.
Continúa en / Continues in: p. 151 
organizations, the media and, even, for public policy institutes, rather than for architecture schools. The above remains strange since the underlying question is how to design a way to channel the massive demand for dwellings to the country's strengthened middle-class majority migrating from the city's Southern periphery while delivering a better quality of urban life.

It is difficult to know why densification and its externalities have attracted little attention in architecture schools as a subject for debate and research. However, after informal chats with several architects - many of them also academics - one could elaborate on some hypotheses that, without pretending to be conclusive, sound reasonable. First, the city's major transformations are not being led from academic circles, but from the market. The complexities of densification are issues that actually affect municipalities, neighbors and the real estate business before universities; that is, the university is detached from the subject. Also, ongoing distrust and distance between academics and the real estate sector influenced the fact that densification was a little discussed and analyzed subject, well before the mayor's tweet. On the other hand, despite being a matter of undisputed social relevance, the design of high-rise residential housing for the middle-class seems to be a much less cool subject for architecture students.

While staying clear of such big issues, architecture schools run the risk of entering a certain condition of public irrelevance, away from topics that matter to the country. It is not about researching and affecting whatever public opinion dictates, however, I think it should react to the signs of a certain loss of leadership within the public sphere. ARQ

\section{Juan Pablo Martínez}


At the same time, land prices are quite low. The Land Registry shows that between February 2011 and December 2016, in the real-estate boom area at Estación Central, developers paid on average USD $990 / \mathrm{m}^{2}$ for the land, which implies a very low incidence in the overall price of the apartments.

Thus, 'vertical ghettos' are actually extraordinary profitable operations for their managers and investors. They are relatively inexpensive to build and are sold at prices well above the average prices of the districts where they are located. Deducting its production costs, the profits of a building of over twenty stories are very high, given the massive scale of construction and the number of marketable units. At Estación Central, we estimate that the benefits per building were about 20 million dollars. In addition, real estate companies do not pay anything back to the State for the valuation of capital gains (López Morales and Sanhueza, 2017). In addition, the 2016 Tax Reform, the mortgage market liberalization, and the recent Pension Fund Law will further increase demand in such a market.

Then, on the one hand, high prices, the small size of the units and the massiveness of high-rise construction can only be controlled through a drastic turn in the current totally privatized housing market, restraining the immense profits that real estate companies get today.

But also, to end the saturation generated by these buildings in neighborhoods, it becomes necessary to adjust the deficient Regulatory Plans of several districts, in order to limit construction heights and densities. Such adjustments must be made simultaneously, averting the 'jump' of real estate companies from one district to another as has already happened in recent decades.

Instead of making denouncements on social networks, state agents must work to make the real estate market comply with the law, generate average profits for companies, compensate the State for capital gains and produce better size and quality housing as required by population, making it more competitive and transparent. In this regard, the Metropolitan Mayor has much to say and do. ARQ

\section{Bibliografía / Bibliography}

LÓPEZ MORALES, E. Y SANHUEZA, C. (20I6) "Inmobiliarias: capturan la mayor plusvalía que genera el Metro, pero tributan muy poco”, Ciper, 26 julio. Disponible en: http://ciperchile.cl/2017/07/26/inmobiliariascapturan-la-mayor-plusvalia-que-genera-el-metro-pero-tributanmuy-poco/

\section{Ernesto López}

Architect and Master in Urban Planning, Universidad de Chile. $\mathrm{PhD}$. in Planning Studies, University College of London. Associate Professor at the Urbanism Department and Academic Coordinator at the Magister in Urbanismo, Universidad de Chile. Researcher at the Center for the Study of Conflict and Social Cohesion (COES). Has published the books Planetary Gentrification (Polity Press, 2016), Global Gentrifications (Policy Press, 2015) and Chile Urbano (Editorial Universitaria, 2013). 


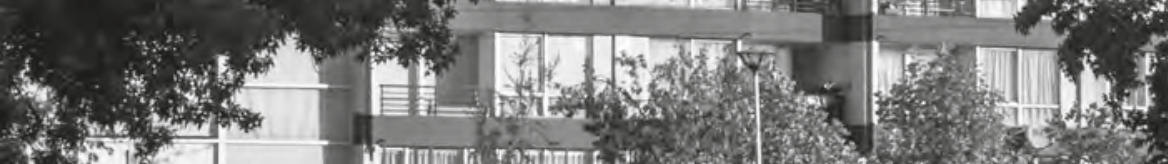

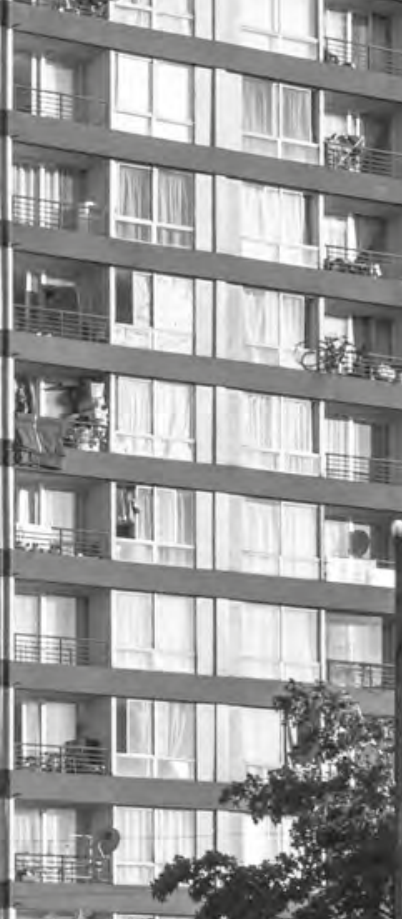

1. 


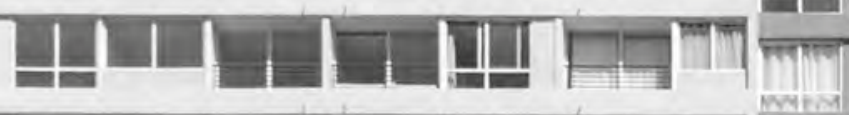

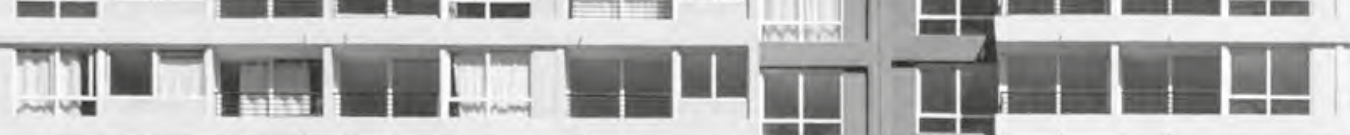

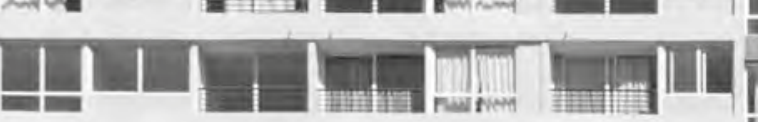

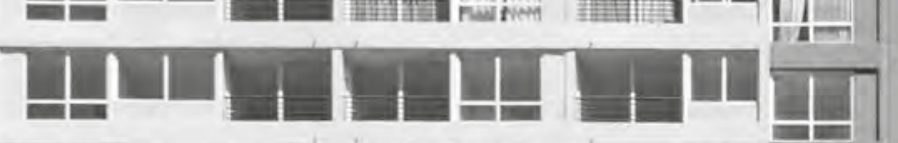

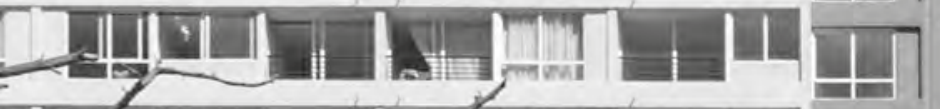

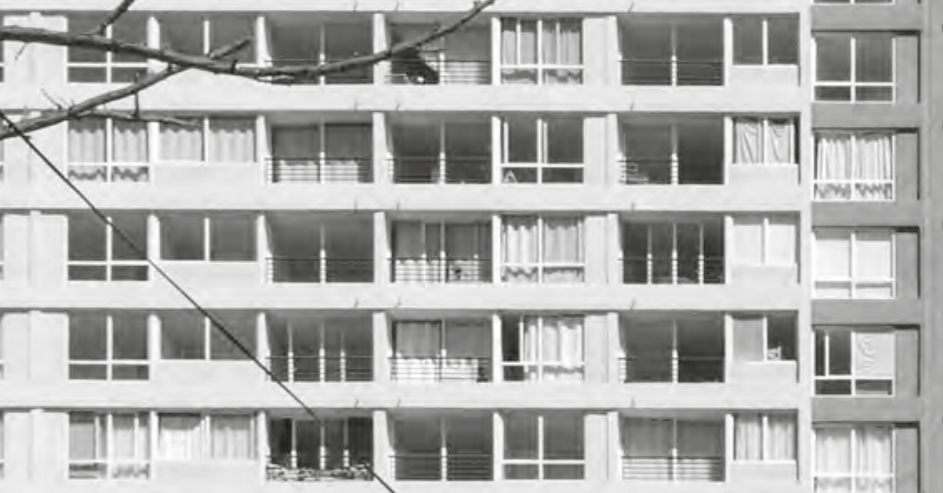
H.

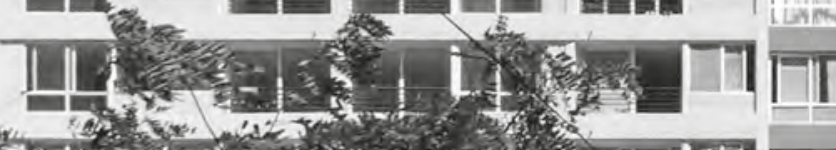

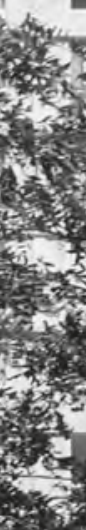
7.

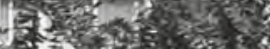

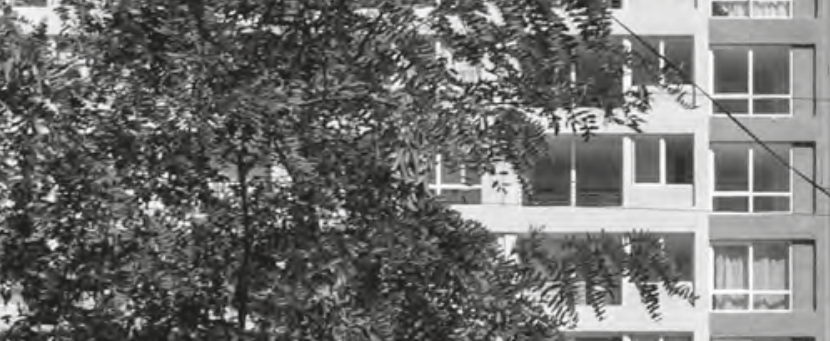

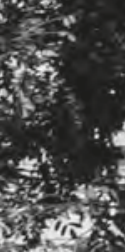

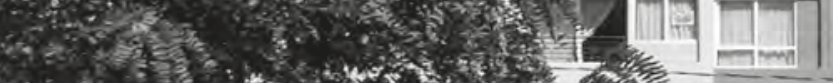

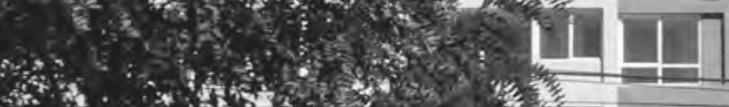

cist:

3

1.
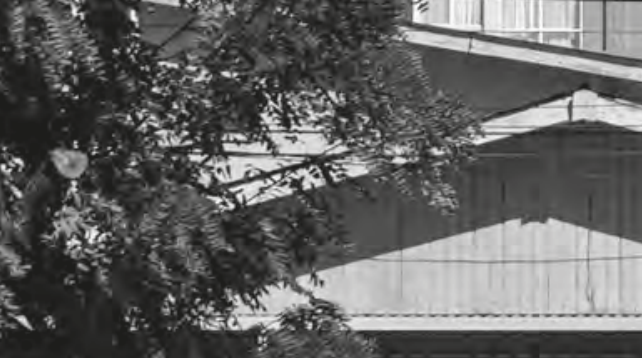
남난 H. H

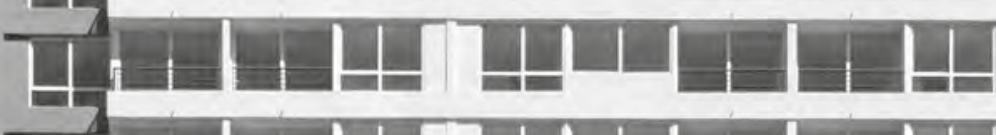

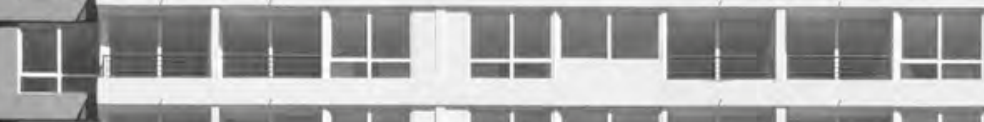

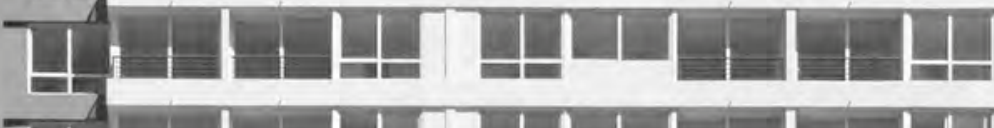
H:

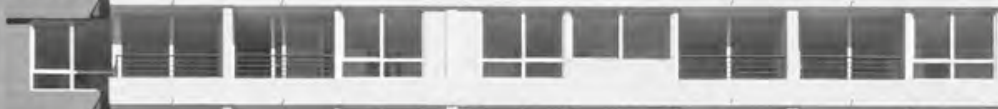

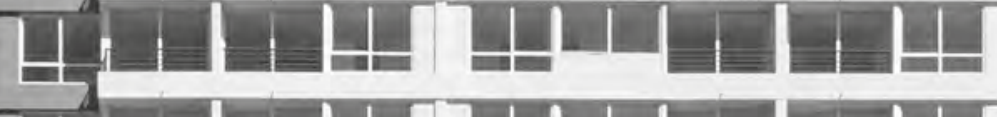

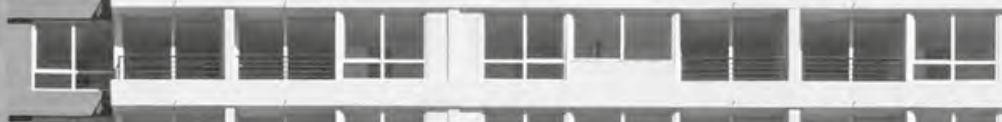

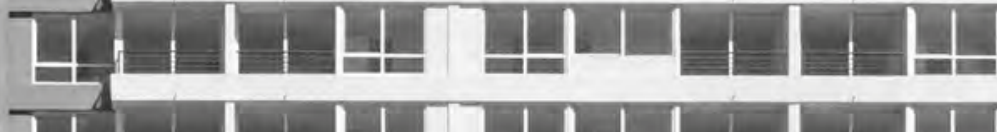

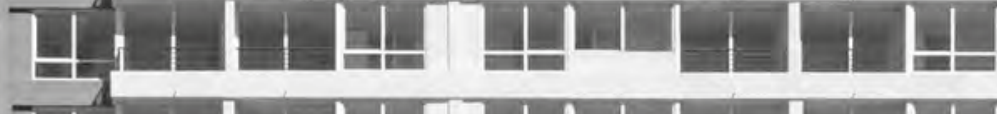

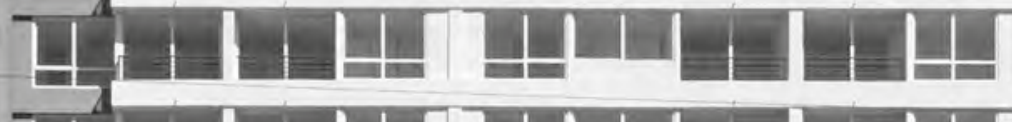

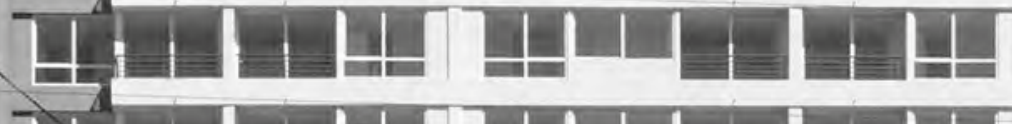

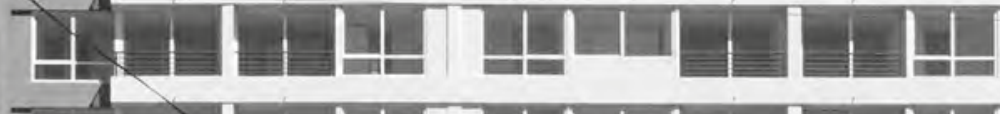

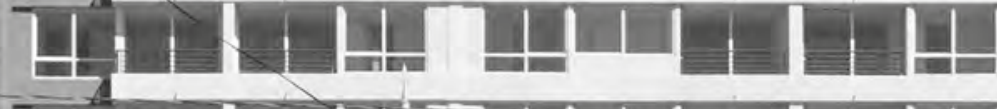

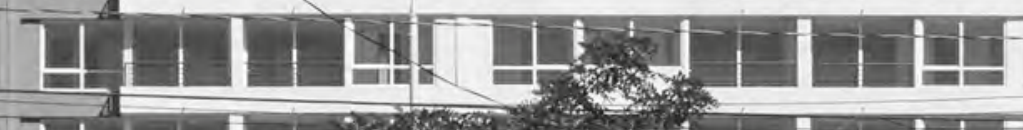

